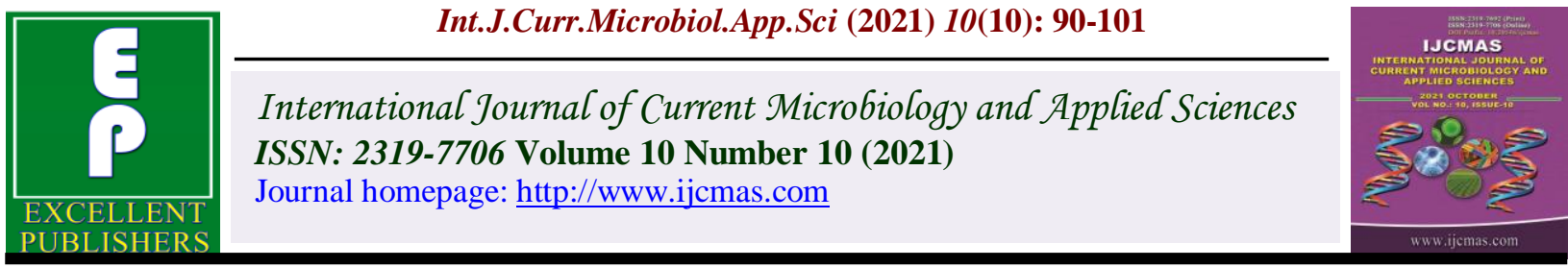

\title{
Studies on Variability and Correlation for Nutrients, Biochemicals and Yield Contributing traits in Brinjal (Solanum melongena L.)
}

\author{
Vishwanath Bidaramali $^{*}$, Shirin Akhtar ${ }^{1}$, Rashmi Kumari ${ }^{1}$, \\ Anupam Das ${ }^{2}$, M. Feza Ahmad ${ }^{3}$ and Chandan Roy ${ }^{4}$
}
${ }^{1}$ Department of Horticulture (Vegetable and Floriculture), ${ }^{2}$ Department of Soil Science and Agricultural Chemistry, ${ }^{3}$ Department of Horticulture (Fruit \& Fruit Tech), ${ }^{4}$ Department of Plant Breeding and Genetics, Bihar Agricultural University, Sabour - 813210, Bhagalpur, Bihar, India

*Corresponding author

\section{A B S T R A C T}

Keywords

Brinjal, Variability, Heritability, Genetic advance, and correlation

Article Info

Accepted: 05 September 2021 Available Online: 10 October 2021
Vegetables are defined as the fresh parts of plants that provide suitable nutrition for humans, raw, cooked, canned, or processed in some other way. Brinjal is a commonly grown economically valuable crop, is an important solanaceous crop in India is a high genotypic diversity. In this study of variability and correlation of nutrient, biochemical parameters, and yield traits of diverse brinjal genotypes. Brinjal is a Wide variability was present among all the nutrients under study suggesting ample scope of selection. Genotypic coefficient of variation (GCV) and phenotypic coefficient of variation (PCV) was high in most of the characters except moisture content, radical scavenging activity, and yield/plant. High heritability was observed for iron (99.70\%), copper (99.01\%), total anthocyanin (99.12\%), total phenol (98.59\%), total chlorophyll content $(92.61 \%)$, average fruit weight $(98.82 \%)$, number of fruits/plant (97.86), suggesting that selection for these traits would be effective for the selection. Correlation study shows that Moisture, P, Ca, TSS, total chlorophyll, fruit length, fruit girth, and a number of fruits per plant showed high significant positive correlation and $\mathrm{Fe}$ and $\mathrm{Zn}$ significant negative correlation with yield per plant at the genotypic level. This study shows that sufficient variability exists in all the cultivars for nutrients, biochemical parameters, and yield traits.

\section{Introduction}

Brinjal (Solanum melongena L.) is one of the most common and popular vegetable crops grown in India and other parts of the globe
(Nandi et al., 2020; Sulaiman et al., 2020 and Bhanushree et al., 2018). In Asia and the Mediterranean Region, Brinjal is among the top five most important vegetable crops (Frary et al., 2007). It is an ancient species of the 
world and originates in the Indo-Chinese center (Vavilov, 1951). The history of eggplant domestication has long been debated, with the most widely accepted hypothesis that eggplants were first domesticated in SouthEast Asia over 4000 years ago (Meyer et al., 2012). It is a potential source of income and nutrients which contribute to the balance of nutrition intake in the local population (Boukare, K. et al., 2019). The different regions of India give a variety of historically recorded accounts of the availability of brinjal and ancient brinjal food preparations during medieval times (Bhat and Vasanthi, 2008). On a worldwide basis, the fruit of most commercial eggplant varieties are purple (Nothmann et al., 1976) Colored dark purple fruit is preferred Consumer with a high content of anthocyanins eggplant varieties are highly variable for fruit color, as well as fruit shape and size (Bhanushree, N. et al., 2018). Varieties of purple, green, or white fruit color in a wide range of color intensities are common in different parts of India (Prasad et al., 2015; Chattopadhyay et al., 2009; Kantharajah, Golegaonkar, 2004). There are about 28 Solanum species found growing as wild in India exhibiting maximum species diversity in the western, eastern peninsular, and northeastern region (Chattopadhyay et al., 2009; Devi et al., 2015; Taher et al., 2017). Brinjal exhibits extensive variation in morphological and biochemical traits (Arivalagan et al., 2012).

Brinjal is nutritionally very important due to its composition, which includes minerals like potassium, calcium, sodium, and iron (Mohamed et al., 2003, Raigon et al., 2008). The fruits possessing high anthocyanin content, low glycoalkaloids, high dry matter, and low levels of phenol are considered excellent for the processing purpose (Bajaj et al.,1979).It has been a high amount of vitamins, phenolics, antioxidants, provides significant nutritional benefits, and has potential pharmaceutical uses as well (Gurbuz et al., 2018). In traditional medicine, Aubergines were also used to treat many diseases. For example, vegetative aerial parts of S. americanum / nigrum are found in parts of Asia. It was traditionally been used to treat skin problems and as a purgative, to relieve urination and increase sex drive (Meyer et al., 2014.) Development of high yield as well as high nutritional brinjal cultivar requires knowledge of existing genetic variation and also the extent of association between characters contributing to yield (Nandi et al., 2020). Direct and indirect effects further will give a clear understanding of their association with yield as well as nutrition. Assessment of variation made on truly diverge germplasm provides an idea about the extent of genetic variation. Greater genetic variability is better for the chances of improvement of the crop (Balas et al., 2019). The study of the variability of crops is not essential for crop improvement, but also effective resource management and germplasm conservation, (Nandi et al., 2020). The present study was conducted to determine the magnitude of the genetic coefficient of variation, phenotypic coefficient of variation, heritability estimates, and expected genetic advancement of genotypes, Along with the nature and extent of the coefficients of correlation.

\section{Materials and Methods}

\section{Plant Materials}

The field experiment at Vegetable Research Farm, BAU, Sabour, and Bhagalpur was carried out. All the nutrients and biochemical analyses were conducted in the well-equipped laboratory of the Department of Horticulture (Vegetable and floriculture) and Department of Soil Science and Agricultural Chemistry, BAC, Sabour. Department of Horticulture (Vegetable and floriculture) at the BAU Sabour, farm, and laboratory in the Kharif 
season during 2016-17 with twenty brinjal genotypes and genetic variability as well as direct and indirect associations among the biochemical and nutrient composition with yield and attributing traits were studied.

\section{Statistical analysis}

Burton and Devine's (1953) suggested method calculated the phenotypic and genotypical coefficients of variation. Sivasubramanian and Menon (1973) classified PCV and GCV as low, moderate, or high; as given $(0-10 \%$ : Low, $10-20 \%$ : Moderate, $20 \%$ and above: High). Heritability in a broad sense $(0-30 \%$, Low: $30-60 \%$, Moderate and $60 \%$ and above High) Is the ratio of genotypical variance to total variance and is calculated by Lush (1940). Genetic advance estimates were obtained through the formula given by Lush (1949) and Johnson et al., (1955). (0 - $10 \%$ : Low, $10-20 \%$ : Moderate and $20 \%$ and above: High). The coefficient of correlation is the mutual association of variables without implying any relationship between cause and effect. Studies on the association between pairs of characters taking formula were determined at genotypical and phenotypic rates by Johnson et al., 1955 and Al-Jibouri et al., 1958.

\section{Results and Discussion}

In India, Brinjal has a broad variability, but the success of the crop enhancement program depends on the genetic variability of germplasm. The magnitude of genetic variability will decide the rate and amount of genetic improvement by hybridization followed by selection. The selection of desirable genotypes is primarily based on mean performance. The mean sum of squares of genotypes for all the proximate nutrients, biochemicals, and yield traits under this study was significant which indicated that wide variability was present among the genotypes for the different characters included in the study. The variability is a combined estimate of genetic and environmental causes. The value of the phenotypic coefficient of variation was higher than the corresponding genotypic coefficient of variation indicating the influence of environmental factors. A better idea can be gained by comparing the relative amount of coefficient of phenotypic and genotypic variance for the actual strength of variability (Sujin et al., 2019: Baswana et al., 2002; Nayak and Nagre, 2013). GCV and $\mathrm{PCV}$ were high in $\mathrm{Cu}, \mathrm{Mn}, \mathrm{Fe}, \mathrm{K}$, and carbohydrate, total anthocyanin, total chlorophyll, total phenolic content, TSS, number of fruits/plant, average fruit weight, fruit girth, and fruit length(Table:01 and Fig: 01). It has obtained Moderate GCV and PCV in crude protein, $\mathrm{N}$, total sugar content, total antioxidants, and radical scavenging activity, whereas low GCV and PCV were observed for $\mathrm{Zn}$ and moisture content For these characters PCV had been marginally higher than GCV, it indicates that lesser role of the environment in the express of these characters according to Burton and Devine's 1953. It gives Moderate GCV and high PCV was observed in $\mathrm{Ca}, \mathrm{P}$, and yield/plant (Table:01 and Fig: 01), suggesting a high influence of environment on these traits. Wide variability was present among all the proximate nutrients under study suggesting ample scope of selection by Sivasubramanian and Menon 1973. In most characters, the genotypic coefficient of variation (GCV) and the phenotypic coefficient of variation (PCV) was high, except for moisture content, yield/plant, radical scavenging activity, and yield/plant (Table:01 and Fig: 01). These are in agreement with previous findings (Chaudhary et al., 2014; Karak et al., 2012; Kumar et al., 2011; Shekar et al.,2012; Bende et al., 2019; Number of fruits per plant (Rani et al., 2017; Ravali et al., 2017); fruit weight (Ravali et al., 2017; Divya and Sharma, 2018); fruit length (Ravali et al., 2017; Divya and Sharma, 2018); 
total fruit yield per plant (Tripathi et al., 2009; Ansari, 2010) number of fruits per plant, fruit weight, fruit length, total fruit yield per plant Balas et al., 2019; a number of fruits per plant (Lohakare et al., 2008; Sherly and Santhi, 2008; Naik et al., 2010; Muniappan et al., 2010; Kumar et al., 2011; Sabeena et al., 2011; Dhaka and Soni, 2012 and Kumar et al., 2013) and moderate for fruit yield per plant (Lohakare et al., 2008 and Dhaka and Soni, 2012), for plant height (Sherly and Santhy, 2008 and Tripathi et al., 2009). Heritability is the proportion of the total variability due to the genetic causes and is an index of transmission of the characters from the parents to their offspring (Falconer, 1960). In this study, high heritability was observed for iron, copper, total anthocyanin, total phenol, total chlorophyll content, average fruit weight, and a number of fruits/plants.

Genetic advance as a percent of mean is high for all proximate nutrients except moisture, $\mathrm{P}$, $\mathrm{Ca}$, and $\mathrm{Zn}$, all biochemical compounds, and all yield traits under study except yield/plant. To have clear predictability of the breeding value, heritability coupled with genetic advance as of mean was found to be effective and more reliable in predicting the result and effect of selection, since high heritability coupled with high genetic advance reflects the preponderance of additive gene action and indicates that selection for the trait may be effective (Falconer, 1960; Panse, 1957).

Moisture content and $\mathrm{Zn}$ showed high heritability with moderate genetic advance, suggesting that mass selection based on these traits could be useful. Moderate values of heritability and genetic advance for $\mathrm{P}$ and yield/plant indicated that deferring selection to later generations may help in improving this trait. Low heritability and moderate genetic advance were observed in $\mathrm{Ca}$ content which suggested a high influence of environment on this trait and that selection would not be much rewarding for the trait. In the present investigation, high heritability coupled with high genetic advance was noticed in all proximate nutrients except moisture, $\mathrm{P}, \mathrm{Ca}$, and $\mathrm{Zn}$, all biochemical compounds, and all yield traits under study except yield/plant. Selection based on these traits would be effective due to the governance of additive gene action. These findings corroborated with the findings of Ramesh Kumar et al., (2013) for fruit length, number of fruits per plant, total phenol content, and fruit yield per plant, Shekar et al., (2012) for fruit length, average fruit diameter, fruit per plant, Naik et al., (2010) for fruit length, number of fruits per plant, yield per plant, Mohanty (2003) for fruit weight and number of fruits, Kumar et al., (2013) for total phenol content and Mili and Bora (2014) for fruits/ per plant. number of fruits per plant (Sabeena et al., 2011; Dhaka and Soni, 2012; Kumar et al., 2013 and Meena and Bahadur, 2014), fruit yield per plant (Kumar et al., 2011; Dhaka and Soni, 2012 and Kumar et al., 2013), average fruit weight, number of branches per plant, length of the peduncle, fruit length, fruit diameter, fruit length: diameter ratio, fresh weight of fruit and phenol. Chaudhary et al., (2014) for fruit weight, fruit yield per plant, fruit length, and total reducing sugar.

\section{Correlation studies}

The degree of association between yield and its components will be studied in correlation (Sujin et al., 2017). The relationship between the dependent and the independent characters reflects the real relationship between the characters and can be performed for such characters to improve the dependent variable (Al-Jibouri et al., 1958). Moisture content (Table: 2) had a highly significant positive association with $\mathrm{N}, \mathrm{P}, \mathrm{K}, \mathrm{Mn}$, TSS, total sugar content, total chlorophyll, fruit length, and a significant positive correlation with yield/plant. 
Table.1 Components of variability in proximate nutrient components, biochemical compounds, and fruit morphological and yield parameters in 20 brinjal genotypes

\begin{tabular}{|c|c|c|c|c|c|}
\hline Characters & GCV & PCV & $\begin{array}{l}\text { Heritability } \\
\text { (Broad } \\
\text { Sense) }\end{array}$ & $\begin{array}{c}\text { Genetic } \\
\text { Advancement } \\
5 \%\end{array}$ & $\begin{array}{c}\text { Genetic } \\
\text { Advancement } \\
\text { as \% of Mean } \\
(5 \%)\end{array}$ \\
\hline \multicolumn{6}{|c|}{ Proximate nutrient components } \\
\hline Moisture ( \% ) & 5.55 & 5.96 & 86.59 & 8.86 & 10.64 \\
\hline Carbohydrate (\%) & 22.47 & 23.12 & 94.44 & 2.37 & 44.98 \\
\hline Crude Protien (\%) & 18.29 & 18.55 & 97.19 & 9.30 & 37.15 \\
\hline Nitrogen $(\%)$ & 15.00 & 15.94 & 88.54 & 1.04 & 29.07 \\
\hline Phosphorous (\%) & 12.13 & 21.22 & 32.68 & 0.06 & 14.28 \\
\hline Potassium (\%) & 23.65 & 24.92 & 90.11 & 1.51 & 46.25 \\
\hline Calcium (\%) & 17.00 & 33.02 & 26.50 & 0.11 & 18.03 \\
\hline Iron $(\mathrm{mg} / \mathrm{kg})$ & 28.02 & 28.77 & 99.70 & 87.90 & 57.64 \\
\hline Manganese (mg/kg) & 28.77 & 28.80 & 99.81 & 110.34 & 59.22 \\
\hline Copper (mg/kg) & 53.77 & 53.81 & 99.84 & 66.07 & 110.67 \\
\hline Zinc (mg/kg) & 5.84 & 6.54 & 79.89 & 7.47 & 10.76 \\
\hline \multicolumn{6}{|c|}{ Biochemical parameters } \\
\hline TSS ( ${ }^{\circ}$ Brix $)$ & 25.56 & 28.25 & 81.89 & 1.18 & 47.65 \\
\hline Total sugar (\%) & 19.86 & 20.67 & 92.31 & 1.39 & 39.31 \\
\hline Ascorbic acid (mg/100g) & 37.10 & 37.43 & 98.22 & 1.72 & 75.74 \\
\hline $\begin{array}{c}\text { Total anthocyanin } \\
(\mathrm{mg} / \mathbf{1 0 0 g})\end{array}$ & 89.01 & 89.41 & 99.12 & 13.99 & 182.56 \\
\hline $\begin{array}{c}\text { Total } \\
\text { chlorophyll(mg/100g) }\end{array}$ & 72.48 & 75.31 & 92.61 & 1.37 & 143.69 \\
\hline $\begin{array}{c}\text { Total phenol } \\
\text { concentration }(\mathrm{CE} \\
\mathrm{mg} / \mathbf{1 0 0 g})\end{array}$ & 50.67 & 51.03 & 98.59 & 6.73 & 103.64 \\
\hline $\begin{array}{l}\text { Total antioxidant ( } \mu \mathrm{mol} \\
\text { Trolox equivalent/g) }\end{array}$ & 19.60 & 20.00 & 96.10 & 0.61 & 39.59 \\
\hline $\begin{array}{c}\text { Radical scavenging } \\
\text { activity }(\%)\end{array}$ & 14.48 & 15.47 & 87.57 & 22.84 & 27.91 \\
\hline \multicolumn{6}{|c|}{ Morphological and yield parameters } \\
\hline Fruit length (cm) & 27.23 & 29.10 & 87.52 & 7.51 & 52.47 \\
\hline Fruit girth $(\mathrm{cm})$ & 29.04 & 29.98 & 93.87 & 8.30 & 57.96 \\
\hline Average fruit weight (g) & 33.60 & 33.80 & 98.82 & 60.27 & 68.81 \\
\hline Number of fruits/plant & 41.16 & 41.60 & 97.86 & 17.66 & 83.87 \\
\hline Yield/plant (kg) & 13.71 & 20.80 & 43.47 & 0.34 & 18.63 \\
\hline
\end{tabular}

Note: GCV: Genotypic Coefficient Of Variation and PCV: Phenotypic Coefficient Of Variation 
Table.2 Estimation of the genotypic correlation coefficient for different characters under

\begin{tabular}{|c|c|c|c|c|c|c|c|c|c|c|c|}
\hline & $\mathbf{M}$ & $\mathbf{P}$ & Ca & $\mathrm{Fe}$ & $\mathbf{Z n}$ & TSS & $\mathbf{T C}$ & FL & FG & NFP & $\mathbf{Y} / \mathbf{P}$ \\
\hline $\mathbf{M}$ & 1 & $0.70^{*}$ & 0.19 & 0.22 & -0.041 & $0.50^{* *}$ & $0.41^{* *}$ & $0.56^{* *}$ & 0.16 & $0.27^{*}$ & $0.47^{* *}$ \\
\hline $\mathbf{P}$ & & 1 & $-0.38^{* * *}$ & $0.76^{* *}$ & $0.27^{*}$ & $0.52^{* *}$ & $0.42^{* *}$ & $0.47^{* *}$ & $0.34^{* *}$ & $0.33^{* *}$ & $0.42^{* *}$ \\
\hline $\mathrm{Ca}$ & & & 1 & 0.04 & $-0.51^{* *}$ & $0.34^{* *}$ & $0.66^{* *}$ & $0.67^{* *}$ & 0.21 & -0.14 & $0.57^{* *}$ \\
\hline $\mathbf{F e}$ & & & & 1 & $0.34^{* *}$ & 0.16 & 0.13 & $0.31^{*}$ & 0.13 & 0.054 & $-0.35^{* * *}$ \\
\hline Zn & & & & & 1 & -0.06 & -0.25 & -0.04 & -0.10 & $-0.43^{* *}$ & $-0.50^{* *}$ \\
\hline TSS & & & & & & 1 & -0.03 & $0.49^{* *}$ & $0.38^{* *}$ & 0.06 & $0.46^{* *}$ \\
\hline TC & & & & & & & 1 & $0.75^{* *}$ & 0.20 & 0.18 & $0.71^{* *}$ \\
\hline FL & & & & & & & & 1 & 0.16 & -0.009 & $0.54^{* *}$ \\
\hline FG & & & & & & & & & 1 & -0.12 & $0.42 * *$ \\
\hline NFP & & & & & & & & & & 1 & $0.36 * *$ \\
\hline $\mathbf{Y} / \mathbf{P}$ & & & & & & & & & & & 1 \\
\hline
\end{tabular}

Note :M : Moisture (\%), P : Phosphorous (\%), K : Potassium Ca: Calcium (\%), Fe: Iron (mg/kg), Zn: Zinc (mg/kg), TSS : Total Soluble Solids $\left({ }^{\circ}\right.$ Brix), TC : Total chlorophyll content $(\mathrm{mg} / 100 \mathrm{~g})$, FL : Fruit length $(\mathrm{cm})$, FG : Fruit girth $(\mathrm{cm}), \mathbf{N F} / \mathbf{P}:$ Number of fruits/plant and Y/P : Yield/plant $(\mathrm{kg})$ 
Fig.1 Graphical representation of proximate nutrient components, biochemical compounds and fruit morphological and yield traits
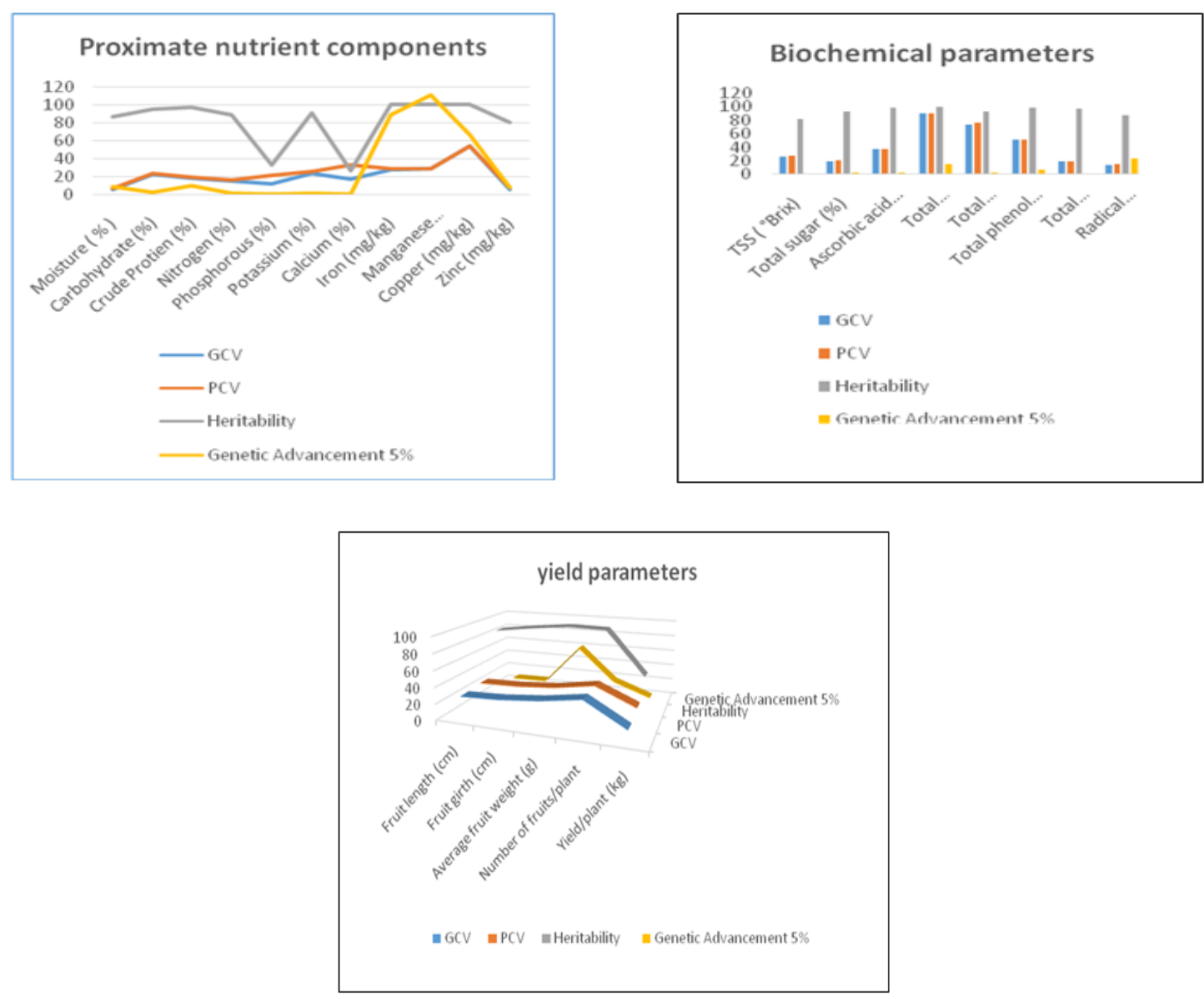

A study was carried out by Dhruve et al., (2014) that moisture content in fruit was significantly positively related to fruit length and fruit weight, anthocyanin content. P showed a highly significant correlation with $\mathrm{Fe}$ and $\mathrm{Mn}$, while it was significantly positively correlated with TSS, total anthocyanin, total chlorophyll, and fruit length. $\mathrm{Ca}$ exhibited a highly significant positive association with total chlorophyll content; significant positive correlation with fruit length, average fruit weight; significant negative correlation with total phenolic content, total antioxidants. Fe showed a highly significant positive association with $\mathrm{Mn}$, significant positive association with $\mathrm{Zn}$, radical scavenging activity, and fruit length.
TSS showed a highly significant positive association with total sugar content and fruit length; a significant positive correlation with fruit girth, yield/plant, and total anthocyanin; whereas, it was significantly negatively correlated with total antioxidants. Total sugar content exhibited a significant positive association with average fruit weight and significantly negatively correlated with ascorbic acid. Wang et al., (2010) for positive correlation of sugar with anthocyanin and TSS with chlorophyll, Ascorbic acid was highly significantly positively correlated with of total chlorophyll content and fruit length. Thangamani and Jansirani (2012) that yield per plant exhibited a significant positive correlation with ascorbic acid content. Total 
anthocyanin showed a highly significant positive association with fruit girth. Total chlorophyll content showed a highly significant positive correlation with fruit length and yield/plant, while it had a significant negative correlation with total phenolic content and total antioxidant. Total phenolic content had a highly significant positive correlation with total antioxidant; it was significantly negatively correlated with fruit length. Tripathi et al., (2014) for linear relation between the total phenolic content and DPPH activities, Total antioxidant had a highly significant negative correlation with fruit length. Fruit Length was highly significantly positively correlated with yield/plant., Akanitapichat et al., (2010) for a positive correlation between antioxidant activities with the total amounts of phenolics. Fruit girth showed a highly significant positive correlation with average fruit weight and a significant positive correlation with yield/plant. Average fruit weight had a highly significant negative correlation with a number of fruits. Chauhan et al., (2017) Fruit yield showed a highly significant and positive association with a number of fruits per plant, Ahmed et al., (2013) fruit yield was significantly positive with no. of fruits per plant, fruit weight. Karak et al., (2012) for a negative correlation between fruit yield per plant and sugar and protein content of fruit and positive correlation between fruit yield per plant and total phenolic content of fruits. Matin et al., (2001) for fruit weight and number fruits per plant, Singh et al., (2010) for yield per hectare being positively correlated with a number of fruits per plant, fruit length, fruit weight, Sharma and Swarop (2000) for fruit yield per plant being positively and significantly associated with a number of fruits per plant and average fruit weight. To initiate an efficient selection program, it is necessary to determine the degree of association of the various quantitative characters. There were coefficients of genotypic association higher than their phenotypic ones. This may be due to the masking effect of the atmosphere that modifies character expression and thereby decreases the phenotypical expression (Nandpuri et al., 1977).

There is a broad range of variations for almost any economically important traits in this crop, and therefore there is an extensive range of improvements through different breeding methods. Fruit length, fruit girth, K, total sugar content, moisture content, $\mathrm{P}$, and total chlorophyll emerged as the most important fruit yield contributing characters of brinjal and these characters may be used as important selection parameters because of their probable conditioning by additive gene action. This indicated the predominance of additive gene action and better scope for improvement of these characters for effective selection of genotype. The correlation may be suggested by Moisture, P, Ca, TSS, total chlorophyll, fruit length, fruit girth, and number of fruits per plant. These are the important corresponding characteristics that contribute to fruit yield in Brinjal and at the same time improve those characters.

\section{References}

Al-Jibouri, H., Miller, P. A., and Robinson, H. F. (1958). Genotypic and environmental variances and covariances in an upland Cotton cross of interspecific origin 1. Agronomy journal, 50(10), 633-636.

Ansari, S. F., Mehta, N., Ansari, S., and Gavel, J. P. (2011). Variability studies in Brinjal (Solanum melongena L.) in Chhattisgarh plains. Electronic Journal of Plant Breeding, 2(2), 275-281.

Arivalagan, M., Gangopadhyay, K. K., Kumar, G., Bhardwaj, R., Prasad, T. V., Sarkar, S. K., and Roy, A. (2012). Variability in mineral composition of Indian eggplant (Solanum melongena L.) 
genotypes. Journal of Food Composition and Analysis, 26(1-2), 173-176.

Balas, A., Jivani, L. L., Valu, M. G., Sakriya, S. G., Gamit, U. C., and Rathod, R. K. (2019). Study of genetic variability and heritability in brinjal (Solanum melongena $\mathrm{L}$.).

Baswana, K. S., Bhatia, M. K., and Duhan, D. (2002). Genetic variability and heritability studies in rainy season brinjal (Solanum melongena L.). Haryana Journal of Horticultural Sciences, 31(1/2), 143-145.

Behera, T. K., Sharma, P., Singh, B. K., Kumar, G., Kumar, R., Mohapatra, T., and Singh, N. K. (2006). Assessment of genetic diversity and species relationships in eggplant (Solanum melongena L.) using STMS markers. Scientia horticulturae, 107(4), 352-357.

Bhanushree, N., Saha, P., Tomar, B. S., Lyngdoh, Y. A., Krishnan, S. G., Gurung, B., and Ghoshal, C. (2018). Genetic analysis and identification of molecular marker linked to the gene for fruit skin colour in eggplant (Solanum melongena L.). Vegetable Science, 45(2), 149-153.

Bhat, R. V., and Vasanthi, S. (2008). Antiquity of the cultivation and use of brinjal in India. Asian Agri-History, 12(3), 169-178.

Boukare, K., Boureima, S., Mariam, K., Djakaridia, T., Zakaria, K., Ernest, T. R., and Pauline, B. K. (2019). Genetic diversity of a collection of Solanum macrocarpon from Burkina Faso revealed by microsatellite markers. International Journal of Genetics and Genomics, $7(2)$ 27.doi:10.11648/j.ijgg.20190702.12

Burton, G. W., and Devane, D. E. (1953). Estimating heritability in tall fescue (Festuca arundinacea) from replicated clonal material 1. Agronomy Journal, 45(10), 478-481.
Caguiat, X. G. I., and Hautea, D. M. (2014). Genetic diversity analysis of eggplant (Solanum melongena L.) and related wild species in the Philippines using morphological and SSR markers. SABRAO Journal of Breeding and Genetics, 46(2), 183-201.

Chadha, M. L., and Paul, B. (1984). Genetic variability and correlation studies in egg-plant (Solanum melongena L.). Indian Journal of Horticulture, 41(1and2), 101-107.

Chattopadhyay, A., Dutta, S., and Hazra, P. (2011). Characterization of genetic resources and identification of selection indices of brinjal (Solanum melongena L.) grown in eastern India. Vegetable Crops Research Bulletin, 74(2011), 3949.

Chattopadhyay, S. B., Sarkar, A., and Hazra, P. (2009). Study on the crossability of three species of Solanum in Gangetic plains of West Bengal. Journal of Crop and Weed, 5(2), 53-56.

Chaudhary, P., and Kumar, S. (2014). Variability, heritability and genetic advance studies in eggplant (Solanum melongena L.). Plant Archives, 14(1), 483-486.

Dahatonde, K., Dod, V. N., Nagre, P. K., and Wag, A. P. (2010). Correlation and path analysis studies in purple fruited brinjal. Asian Journal of Horticulture, 5(2), 428430.

Devi, C. P., Munshi, A. D., Behera, T. K., Choudhary, H., Gurung, B., and Saha, P. (2015). Cross compatibility in interspecific hybridization of eggplant, Solanum melongena, with its wild relatives. Scientia Horticulturae, 193, 353-358.

Dhaka, S. K., and Soni, A. K. (2012). Genetic variability in brinjal (Solanum melongena L.). Asian Journal of Horticulture, 7(2), 537-540.

Dhruve, J. J., Shah, R., Gandhi, S., and Talati, 
J. G. (2014). Biochemical and morphological traits of different cultivars of brinjal fruits growing in Anand (Gujarat). Indian Journal of Agricultural Biochemistry, 27(2), 211214.

Falconer (1960) Introduction to quantitative genetics. Oliver and Boyd http://uf.catalog.fcla.edu/uf.jsp?st=UF02 $1816234 \& \mathrm{ix}=\mathrm{pm} \& \mathrm{I}=0 \& \mathrm{~V}=\mathrm{D} \& \mathrm{pm}=1$

Frary, A., Doganlar, S., and Daunay, M. C. (2007). Eggplant. In: C. Kole (Ed.), Vegetables SE - 9, genome mapping and molecular breeding in plants (pp. 287313). Berlin: Springer.

Gautam, B., and Srinivas, T. (1992). Study on heritability, genetic advance and characters association in brinjal (Solanum melongena L.). South Indian Hort, 40(6), 316-318.

Gürbüz, N., Uluişik, S., Frary, A., Frary, A., and Doğanlar, S. (2018). Health benefits and bioactive compounds of eggplant. Food chemistry, 268, 602-610.

Johnson, H. W., Robinson, H. F., and Comstock, R. E. (1955). Estimates of genetic and environmental variability in soybeans 1. Agronomy journal, 47(7), 314-318.

Kandoliya, U. K., Bajaniya, V. K., Bhadja, N. K., Bodar, N. P., and Golakiya, B. A. (2015). Antioxidant and nutritional components of eggplant (Solanum melongena L.) fruit grown in Saurastra region. International Journal of Current Microbiology and Applied Sciences, 4(2), 806-813.

Kantharajah, A. S., and Golegaonkar, P. G. (2004). Somatic embryogenesis in eggplant. Scientia Horticulturae, 99(2), 107-117.

Karak, C., Ray, U., Akhtar, S., Naik, A., and Hazra, P. (2012). denetie variation and character association in fruit yield components and. Journal of crop and weed, 8(1), 86-89.
Kumar, A., Sharma, V., Jain, B. T., and Kaushik, P. (2020). Heterosis breeding in eggplant (Solanum melongena L.): Gains and provocations. Plants, 9(3), 403.

Kumar, S. R., Arumugam, T., An, C. R., and Premalakshmi, V. (2013). Genetic variability for quantitative and qualitative characters in Brinjal (Solanum melongena L.). African Journal of Agricultural Research, 8(39), 4956-4959.

Kumar, S. R., Arumugam, T., An, C. R., and Premalakshmi, V. (2013). Genetic variability for quantitative and qualitative characters in Brinjal (Solanum melongena L.). African Journal of Agricultural Research, 8(39), 4956-4959.

Kumar, S. R., Arumugam, T., and Premalakshmi, V. (2012). Evaluation and variability studies in local types of brinjal for yield and quality (Solanum melongena L.). Electronic Journal of Plant Breeding, 3(4), 977-982.

Lakshmi, R. R., Padma, S. V., Naidu, L. N., and Umajyothi, K. (2014). Correlation and path analysis studies of yield and yield components in brinjal. Plant Archives, 14(1), 583-591.

Lohakare, A. S., Dod, V. M., and Peshattiwar, P. D. (2008). Correlation and path analysis studies in green fruited brinjal. Asian Journal of Horticulture, 3(1), 173175.

Lush, J. L. (1949). Heritability of quantitative characters in farm animals. Heritability of quantitative characters in farm animals.

Meena, O. P., and Bahadur, V. (2015). Breeding potential of indeterminate tomato (Solanum lycopersicum L.) accessions using D2 analysis. SABRAO journal of breeding and genetics, 47(1), 49-59.

Meyer, R. S., Karol, K. G., Little, D. P., Nee, 
M. H., and Litt, A. (2012). Phylogeographic relationships among Asian eggplants and new perspectives on eggplant domestication. Molecular Phylogenetics and Evolution, 63, 685701.doi:10.1016/j.ympev.2012.02.006

Mili, C., Bora, G. C., Das, B. J., and Paul, S. K. (2014). Studies on variability, heritability and genetic advance in Solanum melongena L. (Brinjal) genotypes. Direct Research Journal of Agricultural and Food Science, 2, 192194.

Mohamed, A. E., Rashed, M. N., and Mofty, A. (2003). Assessment of essential and toxic elements in some kinds of vegetables. Ecotoxicology and environmental safety, 55(3), 251-260.

Mohanty, B. K. (2003). Genetic variability, correlation and path coefficient studies in tomato. Indian Journal of Agricultural Research, 37(1), 68-71.

Mritunjay, T., Pratibha, S., Praveen, P., Pandey, V. R., and Harendra, S. (2014). Antioxidant activities and biochemical changes in different cultivars of brinjal (Solanum melongena L.). American Journal of Plant Physiology, 9(1), 2431.

Nandi, L. L., Saha, P., Behera, T. K., Lyngdoh, Y. A., Munshi, A. D., Saha, N. D., and Tomar, B. S. (2020). Genetic characterisation and population structure analysis of indigenous and exotic eggplant (Solanum spp) accessions using microsatellite markers. The Journal of Horticultural Science and Biotechnology, 1-14.

Nandpuri, K. S., Kanwar, J. S., and Lal, R. (1977). Variability, path analysis and discriminant function selection in tomato (Lycopersicon esculentum Mill.). Haryana J. Hort. Sci, 6, 73-78.

Nayak, B. R., and Nagre, P. K. (2013). Genetic variability and correlation studies in brinjal (Solanum melongena
L.). Origin, composition, seed dissemination and utilization in breeding. Frontier in Plant Science, 8, 1484. doi:10.3389/fpls.2017.01484

Pansc, V. G. and P. V. Sukhatme (1957). Statistical methods for Agricultural Worker. ICAR, New Delhi.

Patel, K. K., and Sarnaik, D. A. (2003). Performance study of long fruited genotypes of brinjal under Raipur conditions. The Orissa J. Hort, 31(1), 74-77.

Prabhu, M., Natarajan, S., Veeraragavathatham, D., and Pugalendhi, L. (2009). The biochemical basis of shoot and fruit borer resistance in interspecific progenies of brinjal (Solanum melongena). EurAsian Journal of BioSciences, 3(1), 50-57.

Prasad M, Mehta N, Dikshit SN, Nichal SS. Genetic variability, genetic advance and heritability in brinjal (Solanum melongena L.). Orissa Journal of Horticulture 2004; 32:26-29.

Prohens, J., Blanca, J. M., and Nuez, F. (2005). Morphological and molecular variation in a collection of eggplants from a secondary center of diversity: Implications for conservation and breeding. Journal of American Society of Horticultural Science, 130, 54-63. doi:10.21273/JASHS.130.1.54

Raigón, M. D., Prohens, J., Muñoz-Falcón, J. E., and Nuez, F. (2008). Comparison of eggplant landraces and commercial varieties for fruit content of phenolics, minerals, dry matter and protein. Journal of food composition and analysis, 21(5), 370-376.

Ram, K. A. I. L. A. S. H., Singh, P., and Singh, R. (2007). Studies on genetic variability and selection parameters for economic characters in egg plant. International Journal of Plant Science, Muzaffarnagar, 2(1), 99-102..

Rani, N., Akhtar, S., Solankey, S. S., Mumari, 
R., Rathod, S., and Siddiqui, M. W. (2017). Genetic Variability among Indian and Exotic Brinjal Genotypes for Reaction against Shoot and Fruit Borer. Environment and Ecology, 35(4C), 3118-3122.

Ravali, B. K., Reddy, R., Saidaiah, P., and Shivraj, N. (2017). Variability, Heritability and Genetic advance in brinjal (Solanum melongena L.). International Journal of Current Microbiology and Applied Sciences, 6(6), 42-47.

Ravali, B., Reddy, K. R., Saidaiah, P., and Shivraj, N. (2017). Genetic diversity in brinjal (Solanum melongena L.). Int. J. Curr. Microbiol. App. Sci, 6(6), 48-54.

Reena, N., and Mehta, A. K. (2009). Genetic variability for some quantitative and qualitative traits in brinjal (Solanum melongena L.). Indian Journal of Tropical Biodiversity, 17(2), 191-196.

Senapati, A. K., and Senapati, B. K. (2006). Character association in relation to infestation by shoot and fruit borer (Leucinodes orbonalis guen.) in brinjal (Solanum meloengena L.). Indian Journal of Agricultural Research, 40(1), 68-71.

Shekar, K., Ashok, P., and Sasikala, K. (2012). Studies on heritability and multivariate analyses in brinjal (Solanum melongena L.). Vegetable Crops Research Bulletin, 76(1), 79-88.

Sherly, J., and Shanthi, A. (2009). Variability, heritability and genetic advance in brinjal (Solanum melongena L.). Research on Crops, 10(1), 105-108.
Shinde, K. G., Bhalekar, M. N., and Patil, B. T. (2012). Characterization of brinjal (Solanum melongena L.) germplasm. Vegetable Science, 39(2), 186-188.

Singh, O., and Kumar, J. (2005). Variability, heritability and genetic advance in brinjal. Indian Journal of Horticulture, 62(3), 265-267.

Singh, P. P., Verma, A. K., and Singh, D. (2018). Evaluation of brinjal genotype under hot arid agro-climate. Indian Journal of Horticulture, 75(3), 451-456.

Sulaiman, N. N. M., Rafii, M. Y., Duangjit, J., Ramlee, S. I., Phumichai, C., Oladosu, Y., and Musa, I. (2020). Genetic Variability of Eggplant Germplasm Evaluated under Open Field and Glasshouse Cropping Conditions. Agronomy, 10(3), 436.

Taher, D., Solberg, S. Ø., Prohens, J., Chou, Y. Y., Rakha, M., and Wu, T. H. (2017). World vegetable center eggplant collection: origin, composition, seed dissemination and utilization in breeding. Frontiers in plant science, 8 , 1484.

Vandana, Y. (2008). Genetic diversity in brinjal germplasm. Asian Journal of Horticulture, 3(2), 315-316.

Vavilov, N. I. (1951). The origin, variation, immunity and breeding of cultivated plants (Vol. 72, No. 6, p. 482). LWW.

Verma, M., Rathi, S., Munshi, A. D., Kumar, A., Arya, L., Bhat, K. V., and Kumar, R. (2012). Genetic diversity of Indian brinjal revealed by RAPD and SSR markers. Indian Journal of Horticulture, 69, 517-522.

\section{How to cite this article:}

Vishwanath Bidaramali, Shirin Akhtar, Rashmi Kumari, Anupam Das, M. Feza Ahmad and Chandan Roy. 2021. Studies on Variability and Correlation for Nutrients, Biochemicals and Yield Contributing Traits in Brinjal (Solanum melongena L.). Int.J.Curr.Microbiol.App.Sci. 10(10): 90-101. doi: https://doi.org/10.20546/ijcmas.2021.1010.012 